\title{
CORPORATE SOCIAL RESPONSIBILITY: A LITERATURE REVIEW
}

\author{
Sanil S Hishan ${ }^{1 *}$, Suresh Ramakrishnan², Nur Naha binti Abu Mansor ${ }^{3}$ \\ 1,2,3 Azman Hashim International Business School (AHIBS), Universiti Teknologi Malaysia, \\ Malaysia
}

${ }^{*}$ Corresponding Author email: hishanssanil@gmail.com

Article History

Submission: May 05, 2020

Revised: June 04, 2020

Accepted: June 25, 2020

\begin{abstract}
Though corporate social responsibility became commonly debated in the last forty years of the twentieth century, at least as early as the nineteenth century, the notion that the company has moral responsibilities became apparent. The corporate social responsibility framework continuously adapts to global market needs. Given the recent advent of corporate social responsibility and sustainability concepts, as well as methodologies and criteria used to meet standards of "fair" business. However, a common connotation of corporate social responsibility (CSR) has not been standardized, although the CSR-related principles and norms are now being established. Between academicians and professionals, there is an increasing concern in corporate social responsibility. Companies are also supposed to be open not only to their creditors but to society at large. Margolis and Walsh (2001) and Orlitzky et al. (2003) presented round-about ninety-five analytical data on CSR and financial results over the period 1972 to 2001. CSR was an independent variable in these studies; while financial output was variable based. Fifty-three percent had a positive relationship with them, twenty-four percent had no partnership with them, nineteen percent had mixed relationships with them, and five percent had harmful relationships with them. Dam (2008) has presented analytical data on CSR and financial results, but there was one difference and one aspect that was normal. The novelty of the study was the distribution of empirical findings in tabulated form focused on asset returns (ROA), equity returns (ROE), selling returns (ROS), Tobin's $Q$, and stock market returns, and it was popular that only empirical findings were tabulated from 1972 to 2001. For companies and prospective scholars, the findings of this study are important regarding corporate social responsibility and consumer behaviour.
\end{abstract}

Keywords: Corporate Social Responsibility; Business Citizenship; Business Multinationals

Abbreviations: NIL

\section{INTRODUCTION}

Since Bowen's (1953) pioneering work on social responsibility inaugurated the new cycle of thought (Carroll, 1999) on corporate social responsibility (CSR), a broad debate on the essence of the subject has been established in the scholarly literature on management (Anderson and Frankle, 1980). In a bibliometric study of a 30-year CSR research period from 1972 to 2002, a particular technique focused on Content Analysis (CA) was created and implemented to explain the course of epistemological growth of CSR. While their findings allowed them to reject that the epistemological evolutionary meaning of CSR had a normative nature, they were unable to distinguish which of the two remaining possibilities, pragmatic or variegation, prevailed over the other, calling for their work to be repeated in a distant future in order to provide proof.

After the 1950s, a new definition of CSR developed, formalized in the 1960s and proliferated in the 1970s (Carroll, 1999). Based on numerous literature studies from the CSR (Carroll, 1999; Engardio et al., 2007; Hart, 1995; Holme and Watts, 2000; McWilliams and Siegel, 2001; Nicolau, 2008; Tsoutsoura, 2004), CSR can be loosely described as the behaviours that render good citizens of corporations that contribute 
to the benefit of society outside their own self-interest. Over the past few decades, various facets of CSR have been the focus of study in academic and business literature and cultural, legal and ethical realms can be epitomized as the most specific components of CSR according to the context of Schwartz and Carroll (2003).

The economic domain is one dimension of CSR, which is important to many financial economists: the financial effect of CSR on profit-seeking companies. As to the relationship between the CSR activities of companies and their results (especially financial output), three statements are provided in the literature. The first group of scholars, focused on Friedman's (1970) point of view, considered a negative association between CSR practices and financial results, as calculated, for example, by shifts in market values (Vance, 1975), excess returns (Wright and Ferris, 1997), or estimates of earnings-per-share analysts (Cordeiro and Sarkis, 1997). Friedman argued that management is selected as agents by the stockholders and their sole responsibility acts on behalf of the best interests of the principals. From the viewpoint of Friedman, the one and only moral obligation of the industry is to utilize its capital to participate in practices aimed at growing owners' income to the property. All other practices that interrupt the optimum distribution of finite capital to alternate purposes have a negative impact on the output of the company. The second party promoted beneficial influences on financial results from the CRS operations of firms (Arago' n-Correa et al., 2008; Bird et al., 2007; Bragdon and Marlin, 1972; Grave and Waddock, 1994; Hart and Ahuja, 1996; Heinze, 1976; Judge and Douglas, 1998; Klassen and McLaughlin, 1996; Nicolau, 2008; Orlitzky et al., 2003; Pava and Krusz, 1996; The statement of this community, focused on stakeholder theory (Freeman, 1984), implies that companies extend the field of concern beyond shareholders in their decision-making and operations to many other constitutions of concerns, such as consumers, staff, suppliers and societies. The second part argues that CSR practices, which include the tacit arguments of all valid stakeholders as stakeholder theory implies, will boost firm interest by (1) immediate cost savings, (2) improving firm credibility, and (3) deterring potential behaviour by regulatory bodies like governments that could place substantial costs on the business A third party supported no apparent association between CSR practices and financial results (Abbott and Monsen, 1979; Alexander and Buchholz, 1978; Aupperle et al., 1985; Teoh et al., 1999), arguing in part for the presence of too many mitigating variables for researchers to discern a specific effect of CSR on firm efficiency.

Seemingly contradictory themes between Friedman's (1970) point of view and stakeholder theory arise from the assumption that CSR, which considers the interests of a broad spectrum of stakeholders (suggested by stakeholder theory), is, in fact, detrimental to the company's value-maximization activities (as asserted by Friedman's point of view). However, Jensen (2001) attempted to resolve the possible tension between these two points of view by introducing wise stakeholder theory, which argues that a company cannot increase its long-term worth if it disregards the desires of multiple stakeholders. And, according to Post et al. (2002), the partnership with both internal and external stakeholders define the potential of a company that produces durable capital over time, and its long-term worth. If CSR leads to maximizing company equity, it may be an effective corporate tactic, as stakeholder 
theory implies, not manipulating the resources of shareholders to support certain groups, as worried by Friedman (1970).

While there are several methods of applying CSR, three widely implemented CSR interventions are sponsorship, cause-related marketing (CRM) and philanthropy. The current research strengthens understanding of CSR interventions by exploring the relative relation of three forms of CSR initiatives, sponsorship, CRM and philanthropy, to the willingness of customers to do so. The more a customer interacts with a company, the greater the probability that he or she may display both in-role and extra-role activities that favour the company. Although several businesses are participating in these three popular CSR programs to improve C-C recognition, little work has been presented to our knowledge regarding their relative impact on the recognition of customers with a company. Such work is therefore critical in providing practitioners with guidance in selecting suitable CSR initiatives to improve C-C recognition, partly because the selected CSR initiative inevitably becomes the company's "arm" (Karaibrahimoglu, 2010).

\section{CSR'S MAIN CHARACTERISTICS}

Each organization is accountable to its stakeholders. Dependent on the size and scope of a product, the stakeholders will vary from staff and customers to vendors, creditors, contractors, states, NGOs and media. In the first place, a corporation is formed to satisfy these stakeholders' financial needs. However, this fiduciary responsibility does not compensate for what Merrick Dodd called the contract that a corporation joins, 70 years ago, the "service to the community" that a business should provide in any sector or society when it works (Karaibrahimoglu, 2010). Accordingly, businesses need a way of repaying their stakeholders' earnings wisely through actively affecting and supporting the neighbourhoods they work within. CSR is a deliberately vague, allembracing philosophy designed to facilitate business activities that go beyond pure fiduciary responsibility. In other terms, in the context of creating a mutually beneficial relationship, CSR is preferably a structure within which a company will control the community in which it works.

What is CSR, then? The amount of meanings available allows preparation for an authoritative answer challenging. By citing Bowen's definition of CSR in 1953, Shalini Taneja and colleagues described CSR as the duty of a corporation to follow behaviour 'in terms of the interests and values of our society' (Vyakarnam, 1992). CSR has adopted a range of meanings, explanations and forms since its inception.

Bowen (1953) sets the scene in this area by proposing that the idea of corporate social responsibility clearly stresses that: 1 . Companies operate for the benefit of the community, and their actions and operational practices will come under the rules established by the community; and 2. Businesses function inside culture as moral agents. Wood (1991) developed these concepts into three guiding principles of social responsibility: (1) enterprise is a social institution and is therefore obligated to use its power responsibly; (2) companies are accountable for the consequences relevant to their areas of interaction in society; and (3) corporate executives are moral agents who are required to exercise their power responsibly. Overall, a firm's social obligations tend to derive from the interaction (and compatibility) of political and cultural 
structures and the economic structure (Jones, 1983). However, Friedman (1970) concluded that our society's efficient functioning depends on the position of its organizations (or systems) to be specialized. According to him, the company is an economic institution and should, therefore, be specialized in the economic sphere; the market will rectify socially responsible behaviour by means of profits. Company has only one social obligation in Friedman's (1970) view, which is to increase its owners' earnings (to secure their property rights). Organizations are regarded as purely legal bodies incapable of making moral judgments. A boss who uses the wealth of a company for non-profit social purposes is deemed to lose economic efficiency and impose an "illegal tax" on the organization. From this point of view, critics (Frederick et al., 1992) question the very basis of Friedman's theory-the economic model. They argue that institutes (or systems) are not working as indicated by the economic model and position specialization.

This stems from the growth of oligopolies in some sectors; the division of ownership and management; the role of policy in the economy; and the intervention of business in the political process by lobbying. Moreover, if businesses do not take "financial responsibilities," government with its inefficiency capacity and offensive bureaucratic practices will be compelled to step in. With regard to Friedman's contention that the legal nature of the articles and memoranda of organizations of firms restricts the participation of a company exclusively to economic positions, it may be argued that they are sufficiently broad to enable deviations from that narrow path.

Social responsibility is also seen as a result and requirement of the extraordinary expansion of the social power of corporations (as shareholders, recruiters, etc.) (Davis, 1975). In the end, failure to combine social power with social responsibility can result in the loss of that power and the company's corresponding decline (Davis, 1975).

Another school of thought believes social responsibility to be a contractual obligation for businesses to society (Donaldson, 1983). In the first place, it is a society that has empowered businesses to use both natural and human capital, giving them the right to execute their competitive functions and to gain their power status (Donaldson, 1983).

As a consequence, the client has a tacit social contract with the company. Thus, the community has a demand on the company and the right to control it, in exchange for the right to exploit capital in the production process. While the particulars of this contract, the alter as social conditions change, this contract, in general, remains the foundation for the legality of the claim or statement of CSR need (Epstein, 1987).

Increasing numbers of academics assume that businesses can no longer be seen simply as private institutions but rather as social institutions (Frederick et al., 1992; Freeman, 1984; Lodge, 1977). The profits that arise from corporations must be spread jointly. This theory is analogous to the stakeholder paradigm (Freeman, 1984) and argues that a company is responsible not only to its shareholders (owners) but to all stakeholders (consumers, workers, investors, etc.) whose participation is important for the survival of a business. Thus, CSR implies that a company should be held accountable for any of its acts affecting people, societies and the world in which those persons or populations exist (Frederick et al., 1992). Carroll (1979) suggests that CSR is 
characterized as the cultural, legal, ethical and discretionary conditions that society places on the company. In the same way, Zanies conceptualized CSR as the degree of "match" between client standards and business ethics. He concludes that CSR is really nothing more than another form of bureaucratic accountability that is the product of bourgeois development. Tuzzolino and Armandi (1981) provide an interesting twist to the debate, presenting a motivating philosophy of social, organizational response based on Maslow's hierarchy of needs. CSR is the satisfaction of the "internal and external self-actualization desires" of a company which are situated at the top of the pyramid of its organizational requirements.

According to this view, companies adopt CSR after meeting three previous layers of needs (including "physiological" or survival needs to be met by corporate profits; "safety needs" such as dividend policy, conglomeration and competitive position; and "affiliate needs" such as trade association participation, lobby groups, etc.). Epstein (1987) attempted to differentiate "business ethics" and CSR and to incorporate them into a strategic process. According to him, "business ethics" applies to the moral issues and dilemmas of corporate behaviour or decisions. CSR relies more on the consequences of corporate behaviour. He defined CSR as the "discernment of business organizations' questions, expectations and claims about the consequences of policies and behaviours on internal and external stakeholders" (Epstein 1987, p. 101). CSR was described by Angelidis and Ibrahim (1993) as "corporate social actions aimed at meeting social needs." We developed a theory of equilibrium based on social demand and supply, describing a set of factors affecting them (financial supply and demand).

Therefore, opinions differ in terms of the CSR base or scope and even the very definition of the term. As a consequence, it can be seen that different aspects of a company's operations are under its control - depending on the position one takes. As has been shown, what can be conceived as "social responsibility" can range from simply maximization of profits to the satisfaction of stakeholders' social needs, or fulfilment of contractual social obligations, the fulfillment of a firm's needs, the achievement of social equilibrium, etc. - depending on the stance taken.

Although academic debate abounds at the theoretical level, perspectives are more scarce at the operational level.

At the time of writing, Schwarts and Dahl noted that North American firms' socially appropriate conduct In the 1970s included: 1. Shareholder disclosure of the information; 2. Disclosure of the Governing Board; 3. Monopoly (predatory pricing, etc.); 4. Minorities equal treatment; 5 . Sharing profit; 6 . Protecting the environment;7. Media ethics; and, 8. Global technical effects.

Nevertheless, according to Vyarkarnam (1992), many of these are now governed by law. Concerns around the current day have shifted direction. He observed that existing CSR issues, significantly the same for both North American and UK businesses, cover fields such as 1. Environmental conservation (e.g. pollution and waste reduction, and resource recycling); 3. Philanthropy (goodwill gifts, etc.); 4 . Societal participation (involving 5. anything from human rights to Hiv education); 6. Urban investment (working with local authorities to generally regenerate small businesses and the inner city environment); and 7. Employee arrangements (higher 
occupational health and safety requirements, good standard of staff care, work sharing, accessibility, etc.)

Empirical research into corporate-responsibility impacts has generated mixed results. Some research indicated a positive relationship, while others claimed the results were detrimental or inconsequential. Belkaoui (1976), for example, was studying the information content of pollution control reports. His findings have indicated a positive relationship, at least in this area, between economic performance and social responsibility. Many experiments also produced results compatible with the idea that financial markets are influenced by corporate social responsibility practices (Anderson and Frankle, 1980; Shane and Spicer, 1983; Spicer, 1978a, b). Some studies did repeat earlier research, however, and had conflicting results. Frankle and Anderson (1978) dismissed Belkaoui's (1976) view, claiming that non-disclosing companies had performed better on the market reliably. Chen and Metcalf (1980) likewise disagreed with Spicer's (1978a, b) assumptions, claiming that his results were motivated by false associations. In answer, Spicer (1980) argued that Chen and Metcalf (1980) misinterpreted the intent of his research, stressing that correlations were being examined which were not causal links. Ingram (1978) reported that in the market segment with which a company is associated, the information content of social responsibility disclosures was conditional.

Alexander and Bulcholz (1978) and Abbott and Monsen (1979) found no significant link between the level of social service activities of a company and the success of the stock markets.

In addition, Chugh (1978), Trotman and Bradley (1981) and Mahapatra (1984) concluded that activities related to corporate social responsibility that result in increased systemic risk. Cochran and Wood (1984) used rankings on corporate social responsibility established by Moskowitz (1972) to check the connection between the practices of corporate social responsibility and the results of the company. A poor positive correlation between corporate social responsibility practices and economic results has been identified after accounting for the sector classification and corporate background. In its study of the connection between social transparency and economic performance, Mills and Gardner (1984) found that companies are more likely to report spending on social responsibility while their financial statements reflect better economic performance.

One disadvantage of the above-mentioned empirical studies is that they failed to distinguish between historical, parallel and subsequent economic performance of CSR, and thus to make accurate inferences regarding causation direction possible. Economic performance covered a span (commonly five years) "surrounding" the performance of CSR and / or the intervals of social disclosure in most previous studies. The success of the CSR and/or social disclosure cycles is regularly the midpoints of that time. However, economic performance cycles were synonymous with the CSR output era in the studies of Mahapatra (1984) and Mills and Gardiner (1984) After the time of CSR release, only Shane and Spicer (1983) looked at the economic performance, seeking a positive association. In fact, McGuire et al. (1988) were the first to split this custom and differentiate economic performance into the historical, parallel and future 
output of the CSR. They used the scores of corporate reputations on Fortune magazine to examine the connection between perceived corporate social responsibility and economic efficiency. Previous company economic success, as calculated by both capital price gains and accounting-based metrics, was considered to be similar to corporate social responsibility than subsequent economic output was to be. McGuire et al. (1988) proposed that economic success could be an important aspect.

Therefore, longitudinal work into the bet-ween partnership between corporate social responsibility and economic performance is ambiguous and far from final. This can be due, according to Ullmann (1985), to the usage of differing and uncertain CSR steps, variations in the testing methodologies and the financial performance steps used. To solve these limits, this report will use a more rigorous assessment of CSR success (in the sense of the UK social and business setting, admittedly), a mix of economic performance metrics and including the required intervening variables in research design.

\section{CSR COMBINED BUSINESS STRATEGY AND OPERATIONS}

Since CSR is founded on the premise that the organization owes duties not only to its shareholders but also to its stakeholders, it follows that it is important to substitute the corporate governance mechanisms and management regimes which accommodate the former to the detriment of the latter. Contemporary corporate governance, whether law-based136 or not, includes accountability about significant equity holding and voting privileges, the discretion of board leaders and main managers, detailed details on their remuneration, and communication with stakeholders and others.

The need for such accountability is not just evidenced by recent business controversies, but also historically integrated into major foreign programs, in particular the corporate governance standards of the 1999 Organisation for Economic Cooperation and Development (OECD) and the OECD guidance for multinationals. In fact, the OECD Corporate Governance Guidelines require the Member States to have meaningful remedies for violations of stakeholder interests where these are covered by the statute. In the end, implementing a CSR strategy allows it to become an essential part of proactive organizational preparation and daily operating efficiency. 140 CSR due diligence will be conducted in the organizational system and across the staff, by continuous preparation and strategic review. Such responsibility applies for the outsourcing of MNEs to manufacturers and other personnel. Some companies also formed CSR divisions to ensure conformity with CSR at both management and manufacturing rates. Over everything, this ethical dimension of management practices must be integrated into the business school curricula and taught as an inherent component of business degrees.

\section{CONCLUSION}

With more exposure to social problems, such as resource depletion and degradation of the climate, what function business can play in society has been a hot issue in recent decades (Vyakarnam 1992). In this sense, analysis and policy recommendations and encourage that the firms not only maximize shareholder value but also align stakeholder interest, including government, workers, societies, and others. 
Companies will consciously presume their social awareness and reveal related information to clients. CSR is no newcomer to the developed world, also known as corporate social responsibility. It becomes a contemporary problem not only for corporations but for the world's customers too. Indeed, there have been a number of suggestive examples, such as Nike Corporation, which has been ostracized for harsh working conditions in East and Southeast Asia, and GAP, which has been attacked for using child labour, or any acts that cause environmental pollution that can also damage a big company's reputation. CSR can be described as "a company's duty to use its resources in ways that benefit society by participating in involvement as a member of society, taking into account society as a whole and enhancing the wellbeing of society as a whole, irrespective of the company's direct profits" (Wood, 1991). The description poses two important points: first, a business that is socially responsible to society as an integral part of its continuing approach should be operated by a company; and second, it is inferred that a business can not be isolated from social issues such as culture and climate. Consequently, these two points lead to the fundamental premise that a corporation is liable not only for maximizing profits but also for protecting the environment and contributing to society's well-being.

Although public attention to CSR has been raised globally, most of the CSR studies conducted so far have been in the background of developed countries such as Western Europe, the USA and Australia (Gray et al., 1995). Positive, optimistic and pessimistic could be the association between corporate social performance and corporate financial results. After evaluating seventeen reports, Griffin and Mahon (1997) addressed the relationship- ship between corporate social performance (CSP) and corporate financial performance (CFP) for the 1970s, twenty-seven studies for the 1980s, and eight studies for the 1990s with a total of fifty-one papers. Seventeen experiments were analyzed in the 1970s with twelve of which was positive relationship pattern. For the 1980s, fourteen out of twenty-seven surveys had accounted for the favourable connection. For the 1990s, seven out of eight surveys had noticed the positive relationship. The negative results were supported in the 1970s by only one test, and in the 1980s, seventeen tests were discovered, and in the 1990s, there were only three studies. The findings for four experiments in the 1970s appeared unconvincing, five studies in the 1980s and nothing reported in the 1990s.

In Griffin and Mahon's study (1997), it is significant that one or more experiments could have one or more results. In fact, Griffin and Mahon's (1997) dissertation isn't all-inclusive. There are few findings that relate to the corporate social success aspect in the 1990s in relation to corporate financial efficiency.

During this time, Frooman (1997), Waddock and Graves (1997), Preston and O'Bannon (1997), Roman et al. (1999) show positive development of the partnership. Wright and Ferris (1997) established the relation's negative course. In addition, in the 2000 decade, a few scholars provided additional elements to the debate on corporate social success and the relation between corporate financial results and different technique settings. The esteemed research works by Ruf et al. (2001), Konar and Cohen (2001), Simpson and Kohers (2002), Murphy (2002) and Orlitzky et al. (2003) had represented a constructive aspect. 
Patten (2002), and Wu (2006) consider the negative relationship. Gray (2006) remained unconvinced about the outcomes between the CSP and CFP ties. However, when observing the retrospective data analysis, Murray et al. (2006) inferred the same conclusions with the help of cross-sectional data analysis, they obtained different results. Hill et al. (2007) examined and described the effect of corporate social responsibility on financial performance with a particular focus on market-based activities and reported optimistic long-term scenario outcomes.

This article argued that it is important to evaluate the common general case for making a more significant contribution to CSR in relation to a given organization's individual weaknesses and opportunities. Such appraisal, in effect, will help to clarify social commitments and thereby guide the design of a CSR plan and decisions on particular CSR projects (if the business case is compelling. Nevertheless, the development and implementation of CSR strategies, in particular assessing corporate social success and communicating with stakeholders, also poses major challenges. As for the validity of CSR programs, there are also potential concerns. Questions about the appropriateness of management activity on social issues could be raised, and there could be a reaction against a well-intentioned CSR initiative; concerns that become even more relevant as CSR takes on a more central role in corporate strategy. Those obstacles could well compromise a business case that would otherwise be compelling. While a business case could be found for many CSR programs, what of those that don't seem to give shareholders much return? Martin indicated that, in the absence of an economic incentive, there would be a need for collective action among certain businesses as well as governments and NGOs. This suggests a requirement for other parties to be involved for GSK and the access issue because of the limited economic incentives for action by the pharmaceutical industry alone (the problem also requires the collaboration of multiple participants, such as healthcare organizations and governments, due to the specialized skills. Nevertheless, it is not yet clear whether these other actors would come to the table; so far, the government's response to demands for donations to the global fund of Kofi Annan is moderate. Another way is to accept the ethical situation and to claim a moral basis for duties to stockholders beyond those. So it was said by the UK For example, company executives will 'balance and play between the conflicting demands of customers, suppliers, employees, creditors and the societies in which it operates.' The consequence of this vision of the firm juggling stakeholder interests - a fiduciary obligation to shareholders aside is that shareholder interests Managers may well, though, choose to use their flexibility in accordance with their views in social management behaviour. In the end, if this behaviour is focused on an objective appraisal of the best interests of society, then the moral situation can, therefore, be compatible with the company's long-term interests. However, unfortunately, there is no certainty that that would always be the case.

In summary, the findings of our analysis suggest that under slack resource theory and good management theory, CSP has no impact on financial performance (CFP)

Under those hypotheses, though, CSP has an impact on market performance. From the analysis, it is clear that CSP has a negative effect on the share's market value but no substantial connection to the firm's D / E conduct. Moreover, it has also been 
shown that CFP has no mediating impact between the CSP and the share's market value, and also between the firm's CSP and debt level (Ali et al., 2010).

\section{Reference:}

Abbott W., Monsen R. (1979). "On the measurement of corporate social responsibility: self-reported disclosure as a measure of corporate social involvement". Acad. Manage. J. 22:501-15.

Alexander G., Bulcholz R. (1978). "Corporate social responsibility and stock market performance". Acad. Manage. J. 21:479-86.

Ali I., Rehman KU., Yilmaz AK., Nazir S., Ali JF. (2010). Effects of corporate social responsibility on consumer retention in cellular industry of Pakistan". Afr. J. Bus. Manage. 4(4):475-485.

Anderson J., Frankle A. (1980). "Voluntary social reporting: an iso-beta portfolio analysis", Account. Rev. 55:468-79.

Angelidis P., Ibrahim N. (1993). "Social demand and corporate supply: a corporate social responsibility model". Rev. Bus. 15:7-10.

Aragon-Correa JA., Hurtado-Torres N., Sharma S., Garcia-Morales JV. (2008). 'Environmental Strategy and Performance in Small Firms: A

Resource-Based Perspective'. J. Environ. Manage. 86(1):88-103. Belkaoui A (1976). "The impact of the disclosure of the environmental effects of organization behaviour on the market". Financial Manage. 5(4):6-31.

Bowen HR. (1953). Social Responsibilities of the Businessman, Harper \& Row, New York, NY.

Carroll AB. (1979). "A three-dimensional model of corporate performance". Acad. Manage. Rev. 4(4):497-505.

Carroll AB. (1999). Corporate social responsibility: evolution of a definitional construct. Bus. Soc., 38(3):268-295.

Chen K., Metcalf R. (1980). "The relationship between pollution controlbrecord and financial indicators revisited". Account. Rev. 55:168-77. Chugh E (1978). "Impact of pollution control regulations on the marketnrisk of securities in the US". J. Econ. Stud. 16(2):67.

Cochran P., Wood R. (1984). "Corporate social responsibility and financial performance". Acad. Manage. J. 27(1):42-56.

Davis K. (1975). "Five propositions for social responsibility", Business Horizons. 18(3):19-24.

Donaldson T. (1983). "Constructing a social contract for business" in Donaldson, T. and Werhane, P. (Eds), Ethical Issues in Business, Prentice-Hall, Englewood Cliffs, NJ. pp.153-65.

Epstein E. (1987a). "The corporate social policy process and the process of corporate governance". Am. Bus. Law J. 25:361-83.

Epstein E. (1987b). "The corporate social policy process: beyond business ethics, corporate social responsibility and corporate social responsiveness". California Manage. Rev. 29(3):99-114.

Frankle A., Anderson J. (1978). "The impact of the disclosure of environmental effects of organizational behaviour on the market: comment". Financial Manage. 21:92-107.

Frederick WC., Post JE., Davis K. (1992), Business and Society, McGraw-Hill International, New York, NY.

Freeman RE. (1984). Strategic Management: A Stakeholder Approach, Pitman, Boston, MA.

Friedman M. (1970). "The social responsibility of business is to increase its profits", New York Times Magazine, 13 September. P33+.

Graves SB., Waddock SA. (1994). "Institutional owners and corporate social performance". Acad. Manage. J. 37(4):1034-46.

Griffin JJ., Mahon JF. (1997). "The Corporate Social Performance and Corporate Financial Performance Debate: Twenty-Five Years of Incomparable Research," Bus. Soc. 36(5):5-31

Karaibrahimoglu Y. (2010). "Corporate social responsibility in times of financial crisis". Afr. J. Bus. Manage. 4(4):382-389. 
Schwartz MS., Carroll AB. (2003). Corporate Social Responsibilty: A three-domain approach. Bus. Ethics Quarterly 13(4):503-530

Spicer B. (1980). "The relationship between pollution control record and financial indicators revisited: further comment". Account. Rev. 55:178-185.

Trotman K., Bradley G. (1981). "Association between social responsibility disclosure and characteristics of companies". Account. Org. Soc. 6:355-362.

Tuzzolino F., Armandi B. (1981) "A need - hierarchy framework for assessing corporate social responsibility". Acad. Manage. Rev. 6(1):21-8.

Ullmann A (1985). "Data in search of a theory: a critical examination of the relationships among social performance, social disclosure, and economic performance of US firms". Acad. Manage. Rev. 10(3):540-557.

Vance S.C. (1975). "Are socially responsible corporations good investment risks?" Manage. Rev. 64:1824.

Vyakarnam S. (1992). "Social responsibility: what leading companies do", Long Range Planning. 25(5):59-67.

Wood D. (1991). "Corporate social performance revisited". Acad. Manage. Rev. 16(4):758-69. 